\title{
Yields, Quality and Suitability of Four Annual Forages for Deer Pasture in North Central Alberta
}

\author{
Grant Chapman ${ }^{1}$, Edward Bork ${ }^{1}$, Noble Donkor ${ }^{*}, 2$ and Robert Hudson ${ }^{3}$ \\ ${ }^{I}$ Department of Agricultural, Food and Nutritional Science, University of Alberta, Edmonton, AB, T6G 2P5, Canada \\ ${ }^{2}$ Department of Biology, Canadian University College, Lacombe, AB, T4L 2E5, Canada \\ ${ }^{3}$ Department of Renewable Resources, University of Alberta, Edmonton, AB, T6G 2E1, Canada
}

\begin{abstract}
Field pea (Pisum sativum), canola (Brassica napus), turnips (Brassica rapa) and Berseem clover (Trifolium alexandrinum) were grown in north central Alberta to assess their potential yield and quality and to evaluate their utilization and preference by white-tailed deer. Herbage DM yield, crude protein (CP), neutral detergent fiber (NDF), absolute and relative herbage utilization, and dietary preference were the criteria used. The four annual forages produced over 3, 000 to $11,000 \mathrm{~kg} \mathrm{ha}^{-1} \mathrm{DM}$ with canola and turnips producing higher DM yields than field pea and berseem clover. Forage CP for the four seeded forages ranged from 140 to $305 \mathrm{~g} \mathrm{~kg}^{-1} \mathrm{DM}$ with canola and turnips having higher CP concentrations than field pea and berseem clover. NDF concentrations ranged from 246 to $480 \mathrm{~g} \mathrm{~kg}^{-1} \mathrm{DM}$ and were lowest in turnips, intermediate in field pea, and highest in canola and berseem clover. Absolute herbage utilization remained similar $(\mathrm{P}>0.05)$ among the four forage species. In contrast, relative herbage utilization was greater from berseem clover $(66 \% \mathrm{DM})$ than field pea $(42 \% \mathrm{DM})$ or canola $(22 \% \mathrm{DM})$ or turnips $(20 \% \mathrm{DM})$. Differences in dietary preference occurred among the four forages (berseem clover $\geq$ field pea $\geq$ turnips $\geq$ canola). These results suggest that annual forages, especially berseem clover and field pea, show promise for increasing forage yield and quality and suitability for late season grazing.
\end{abstract}

Keywords: Berseem clover, canola, field pea, quality, suitability, turnips, yield.

\section{INTRODUCTION}

Annual forages are commonly used in livestock production systems throughout the world and complement or provide valuable alternatives to perennial forages. Incorporating annuals in a grazing system rapidly increases short-term pasture forage options during times when perennial forages are not available. Annual forages are used on the prairies of Western Canada for silage and pasture production [1,2]. Studies in British Columbia [3], Montana [4] and Atlantic Canada [5] have demonstrated the potential of Persian clover (Trifolium resupinatum L.) and berseem clover ( $T$. alexandrinum $L$.) for high-quality forage. In Michigan, annual medics (Medicago spp.) and berseem clover provided an extra source of emergency forage when alfalfa (Medicago sativa L.) was winter killed [6]. Berseem clover, arrowhead clover (T. vesiculosum L.) and winter vetch (Vicia villosa subsp. varia $\mathrm{L}$ ) have shown promise for high $\mathrm{N}$ accumulation and forage production in Alaska [7]. While research on annual forage production and quality has been conducted for the cattle industry in western Canada [2, $8,9]$, little research has assessed the suitability of annual forages for deer pasture. Annual forages can be utilized to provide alternative forage during perennial pasture rejuvenation on deer pastures, a frequent requirement due to the highly selective foraging behavior of deer and removal of preferred forages from pasture swards.

\footnotetext{
*Address correspondence to this author at the Department of Biology, Canadian University College, Lacombe, AB, T4L 2E5, Canada; Tel: 403782-3381, Ext. 4186; E-mail: ndonkor@cauc.ca
}

There is limited information on the adaptability of annual forages on deer pastures and performance of deer on annual forages in northern temperate environments such as those in north central Alberta. The objectives of this study were to evaluate the biomass production, crude protein (CP) and neutral detergent fiber (NDF) concentrations of four annual forages, including field pea (Pisum sativum L.), Argentine "Skyhawk" canola (Brassica napus L.), "Samson" turnips (Brassica rapa var. rapa L.) and berseem clover (Trifolium alexandrinum L). Additional objectives were to compare the utilization and dietary preferences of white-tailed deer (Odocoileus virginianus) grazing these forages.

\section{MATERIALS AND METHODS}

\section{Experimental Procedure}

Seed bed preparation was done in May 2003 using a broadcast application of glyphosate herbicide at a rate of 4.8 $\mathrm{L}^{\mathrm{h}} \mathrm{C}^{-1}$, followed by extensive disking and harrowing. The predominant soil type was an Orthic Gray Luvisol of the La Corey, Plamondon and Spedden series. The seed bed was fallowed for one year and on 3 June 2004, field pea, canola, turnips and berseem clover were seeded with a 3-m wide Brillion forage seeder into plots following a randomized complete block design with two blocks. The two blocks served as two replicates of two pastures of 0.28 ha for each of the seeded forages. These pastures were fenced with $2.7 \mathrm{~m}$ high page wire into one large enclosure with a gate. The pastures were used to evaluate resource selection by deer. Seeding rates were 6 bushels/ha, 11, 7.6 and $13.7 \mathrm{~kg} \mathrm{ha}^{-1} \mathrm{DM}$ for field pea, canola, turnips and berseem clover, respectively. Field pea and berseem clover were 
neither treated with fungicides and insecticides nor fertilized. Canola seeds were treated with blue coat and helix fungicide and insecticide. Turnips were treated with phosphate.

\section{Forage Evaluation}

Aboveground forage quality was evaluated on 20 June 2004, 17 days after planting (DAP), 4 August 2004 (73 DAP) and on 15 August 2004 (84 DAP) to determine seasonal changes in annual forage crude protein (CP) and neutral detergent fiber (NDF) concentrations. Plant parts (leaf and stem) quality was also evaluated on 4 August 2004 to emulate deer forage selectivity during late summer. Forage dry matter yield was evaluated on 15 August 2004. All data were collected by sampling four, $0.5 \times 0.1 \mathrm{~m}$ randomly placed quadrats within each plot. All samples were dried at $60^{\circ} \mathrm{C}$ to constant weight and ground to pass a $1-\mathrm{mm}$ screen using a Wiley Mill. CP concentration was determined from nitrogen levels $(\mathrm{CP}=6.25 \mathrm{X} \mathrm{N})$ using a LECO FP-528 nitrogen auto-analyzer [10]. NDF concentration was determined using the ANKOM filter bag technique [11].

\section{Resource Selection}

The single enclosure containing the two replicates of two pastures of 0.28 ha field pea, canola, turnips and berseem clover was stocked with seven adult white-tailed bucks with mean initial live weight $( \pm \mathrm{SD})$ of $50.5( \pm 3.7) \mathrm{kg}$ from 4 August to 15 August, 2004, to determine the time spent grazing in each forage type and to quantify actual forage removals. Deer were observed in 3 trial periods (Early - days 3 to 6; Mid - days 7 to 9; and Late - days 10 to 12).

During daily observation periods of 75 minutes, the number of actively foraging deer on each plot and forage type were recorded 15 times at 5 minute intervals. These frequency data were then summed within each forage type across the 15, 5 minute interval scans and divided by the total number of deer observed grazing to calculate the proportion of total deer foraging within each of the 8 forage plots. These estimates were compared among forage types within each trial period and across the entire trial and used as index of forage preference.

Forage biomass availability $\left(\mathrm{kg} \mathrm{ha}^{-1} \mathrm{DM}\right)$ and absolute utilization $\left(\mathrm{kg} \mathrm{ha}^{-1} \mathrm{DM}\right)$ were measured by clipping $0.5 \mathrm{~m} \times 1.0$ $\mathrm{m}$ quadrats inside and outside each of 3 grazing exclosures (1.5 $\mathrm{x} 1.5 \mathrm{~m}$ ) within each of the 2 plots for each forage type. Absolute forage utilization at each exclosure was determined as the difference between grazed and ungrazed quadrats for the seeded forage within each forage type. Moreover, relative forage utilization (\%) was calculated as the proportion of dry matter removed in each forage type. Bork et al. [12] suggest information on both absolute and relative forage utilization are important, as these parameters emphasize grazing impacts from the perspective of the grazing animal and plant community, respectively. The research protocol (2003A061) was approved by the animal policy and welfare committee, Faculty of Agricultural, Life and Environmental Sciences at the University of Alberta following guidelines of the Canadian Council on Animal Care.

\section{Data Analysis}

Data were subjected to analysis of variance (ANOVA) using PROC Mixed of SAS [13], where seeded forage type was a fixed factor. Measured response variables in this study included DM yield, herbage quality (CP and NDF) and foraging responses (utilization and foraging time). Post-hoc mean comparisons were done on all significant treatment means using Tukey's method ( $\mathrm{p} \leq 0.05)$.

\section{RESULTS AND DISCUSSION}

\section{Forage Dry Matter Yield}

Dry matter yields were the highest for canola $(11,196 \mathrm{~kg}$ $\left.\mathrm{ha}^{-1} \mathrm{DM}\right)$, and were significantly $(\mathrm{P}<0.05)$ higher than turnips $\left(5959 \mathrm{~kg} \mathrm{ha}^{-1} \mathrm{DM}\right)$, berseem clover $\left(4368 \mathrm{~kg} \mathrm{ha}^{-1}\right.$ DM) and field pea (3001 kg ha ${ }^{-1}$ DM) (Fig. 1). Of the four forages, berseem clover seems to be the one that has been evaluated by most researchers. The dry matter yield for berseem clover (4368 $\left.\mathrm{kg} \mathrm{ha}^{-1} \mathrm{DM}\right)$ at $84 \mathrm{DAP}$ in the current research was lower than results obtained for berseem clover biomass $\left(6000 \mathrm{~kg} \mathrm{ha}^{-1} \mathrm{DM}\right)$ at 76 DAP in a study in Edmonton, Alberta by Ross et al. [9], and those obtained by Brink et al. [14] for berseem clover at 61 DAP in Mississippi. However, the results of the current study compare favorably with berseem clover in late-May in Italy which yielded 3000-5000 kg ha ${ }^{-1} \mathrm{DM}$ [15] and berseem clover sown in northern USA which yielded $4000 \mathrm{~kg} \mathrm{ha}^{-1}$ DM at 90 DAP [6]. Our field pea yields (3001 $\left.\mathrm{kg} \mathrm{ha}^{-1} \mathrm{DM}\right)$ were also well below those obtained in a study from southern Alberta $\left(5452 \mathrm{~kg} \mathrm{ha}^{-1} \mathrm{DM}\right)$ in a study by Fraser et al. [2]. However, the latter study was conducted under intensively managed and irrigated conditions on Dark Brown Chernozem soils, conditions markedly different from the northern temperate Boreal environments examined in the current study. Differences in the observed forage yields can be attributed to variation in soil quality and growing season length, together with agronomic practices of heavy fertilization and irrigation.

\section{Forage Quality}

Total aboveground forage $\mathrm{CP}$ concentrations of the seeded forages 17 DAP ranged from 176 to $305 \mathrm{~g} \mathrm{~kg}^{-1} \mathrm{DM}$ (Fig. 2), and were highest in turnips and lowest in berseem clover. By 4 August (73 DAP) the total aboveground forage $\mathrm{CP}$ concentrations of the seeded forages had declined to a range of 150 to $200 \mathrm{~g} \mathrm{~kg}^{-1} \mathrm{DM}$, and were highest in field pea and lowest in berseem clover. In contrast, total aboveground forage $\mathrm{CP}$ concentrations were similar $(\mathrm{p}>0.05)$ among forage types at $84 \mathrm{DAP}$, ranging from 140 to $147 \mathrm{~g} \mathrm{~kg}^{-1} \mathrm{DM}$. Thus, between 17 and 84 DAP CP concentrations significantly decreased $(\mathrm{P}<0.05)$ in all four seeded forages (Fig. 2). The CP concentrations obtained in the current study are comparable to other studies. For example, Ross et al. [9] found that between 35 and $88 \mathrm{DAP}, \mathrm{CP}$ concentration of berseem clover declined from 310 to $180 \mathrm{~g} \mathrm{~kg}^{-1} \mathrm{DM}$. The CP concentrations of berseem clover were also consistent with ranges of 180 to $270 \mathrm{~g} \mathrm{~kg}^{-1} \mathrm{DM}$ found by Duke et al. [16] and $180-300 \mathrm{~g} \mathrm{~kg}^{-1} \mathrm{DM}$ found by Guessous et al. [17] and $140 \mathrm{~g} \mathrm{~kg}^{-1} \mathrm{DM}$ after 70 DAP by [14]. The CP concentrations for the four annual forages evaluated in this study are higher than those observed by Tanciera et al. [7] in interior Alaska. Leaves of all seeded forages contained higher $(\mathrm{P}<0.05)$ crude protein concentrations than stems (Table 1). Crude protein concentration was particularly high in field pea and canola. 


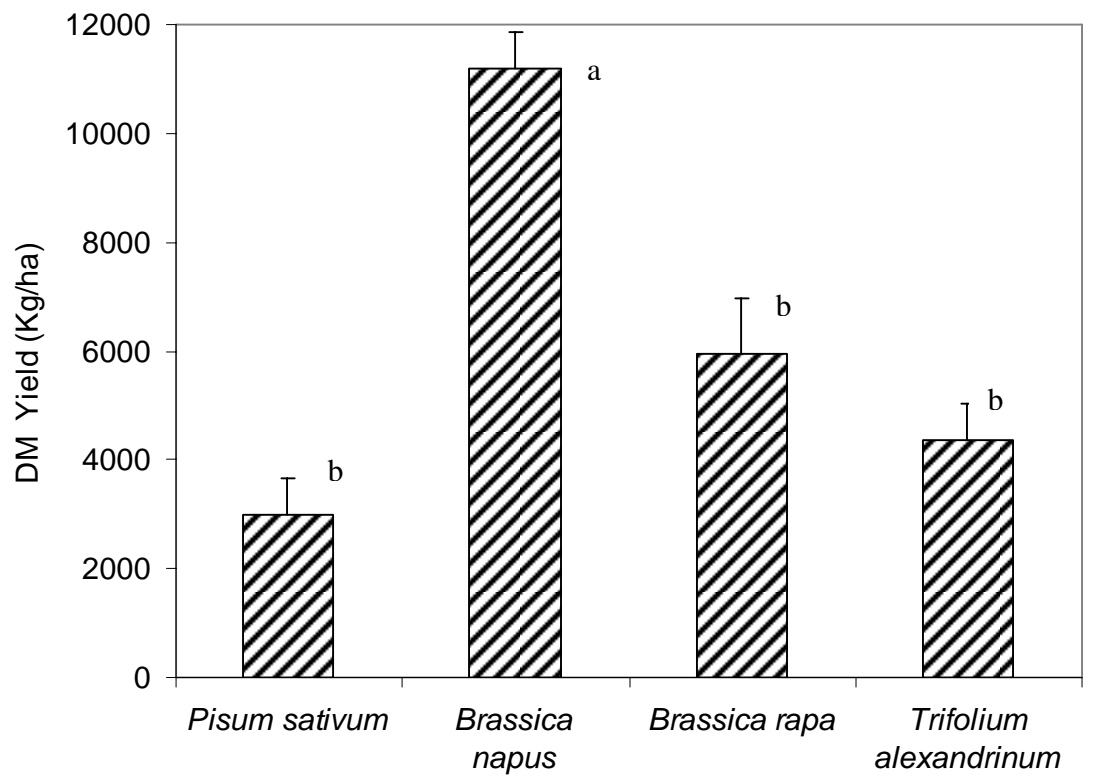

Fig. (1). Mean (with SE bars) dry matter yield of annual forages harvested 15 August 2004 (84 DAP). Means with different letters differ, $\mathrm{p}<0.05$.

Aboveground forage NDF concentrations of the seeded forages after 17 DAP ranged from 246 to $480 \mathrm{~g} \mathrm{~kg}^{-1} \mathrm{DM}$ and were lowest in the turnip plants, intermediate in field pea, and highest in canola and berseem clover (Fig. 3). By 73 DAP, similar trends of NDF concentrations were obtained from the four seeded forages, ranging from 280 to $470 \mathrm{~g} \mathrm{~kg}^{-1}$ DM. By August 15 (84 DAP) NDF concentrations of the seeded forages remained highest in canola, intermediate in berseem clover and field pea, and lowest in turnips (a range of 420-480 $\left.\mathrm{g} \mathrm{kg}^{-1} \mathrm{DM}\right)$. NDF concentrations did not significantly differ $(\mathrm{P}>0.05)$ from 17 and 84 DAP in all four seeded forages (Fig. 3). With the exception of turnips, all the other three forages had lower NDF concentrations in their leaves than in their stems (Table 1). NDF concentrations were lowest in pea and canola leaves. Declines in digestibility in forages have been linked to factors such as stem properties [14]. Stem accumulation has the greatest potential negative impact on the forage quality of annual forages, with digestibility of stems declining at a greater rate than that of leaves.

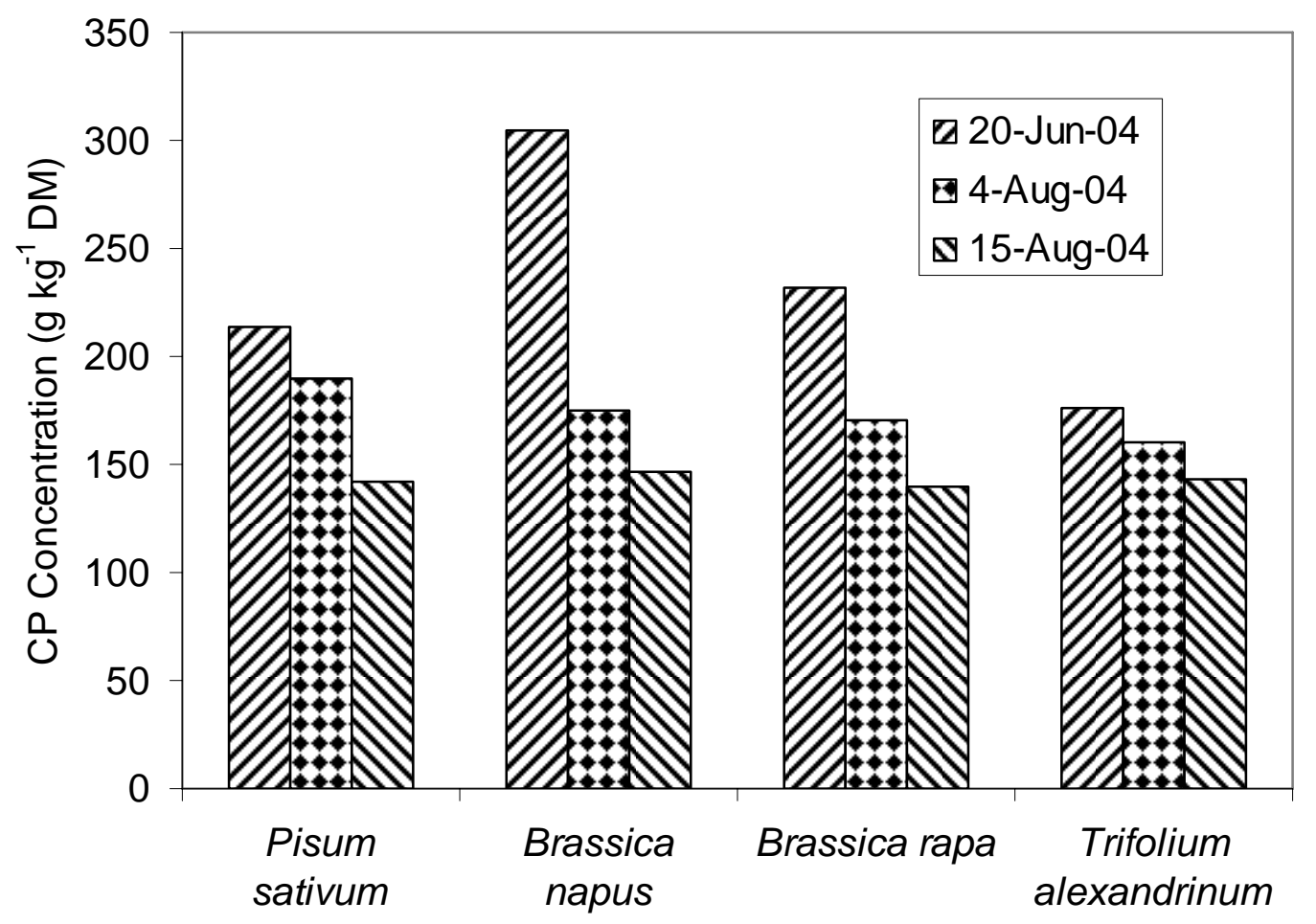

Fig. (2). Total aboveground forage crude protein (CP) concentrations of seeded forages sampled 20 June 2004 (17 DAP), 4 August 2004 (73 DAP) and 15 August 204 (84 DAP). 
Table 1. Mean (SE in Parentheses) Chemical Measures of Forage Parts in Pisum sativum, Brassica napus, Brassica rapa, and Trifolium alexandrinum, Sampled 4 August 2004 (73 DAP)

\begin{tabular}{|c|c|c|c|c|}
\hline \multirow{2}{*}{ Forage Type } & \multicolumn{2}{|c|}{ Crude Protein } & \multicolumn{2}{|c|}{ Neutral Detergent Fiber } \\
\cline { 2 - 5 } & Leaf & Stem & \multicolumn{2}{|c|}{$\left.\mathbf{( g ~ k g}^{-1} \mathbf{D M}\right)$} \\
\cline { 2 - 5 } & $270(10) \mathrm{a} \mathbf{a}^{\mathrm{z}}$ & $100(5) \mathrm{b}$ & $275(11) \mathrm{b}$ & $425(13) \mathrm{a}$ \\
\hline \hline Pisum sativum & $260(8) \mathrm{a}$ & $80(4.5) \mathrm{b}$ & $280(12) \mathrm{b}$ & $480(15) \mathrm{a}$ \\
\hline Brassica napus & $230(8) \mathrm{a}$ & $130(6.1) \mathrm{b}$ & $300(12) \mathrm{a}$ & $300(13) \mathrm{a}$ \\
\hline Brassica rapa & $240(9) \mathrm{a}$ & $80(5.5) \mathrm{b}$ & $350(13) \mathrm{b}$ & $480(14) \mathrm{a}$ \\
\hline Trifolium alexandrinum & & &
\end{tabular}

${ }^{Z}$ Within a column, means with different letters differ, $\mathrm{p}<0.05$.

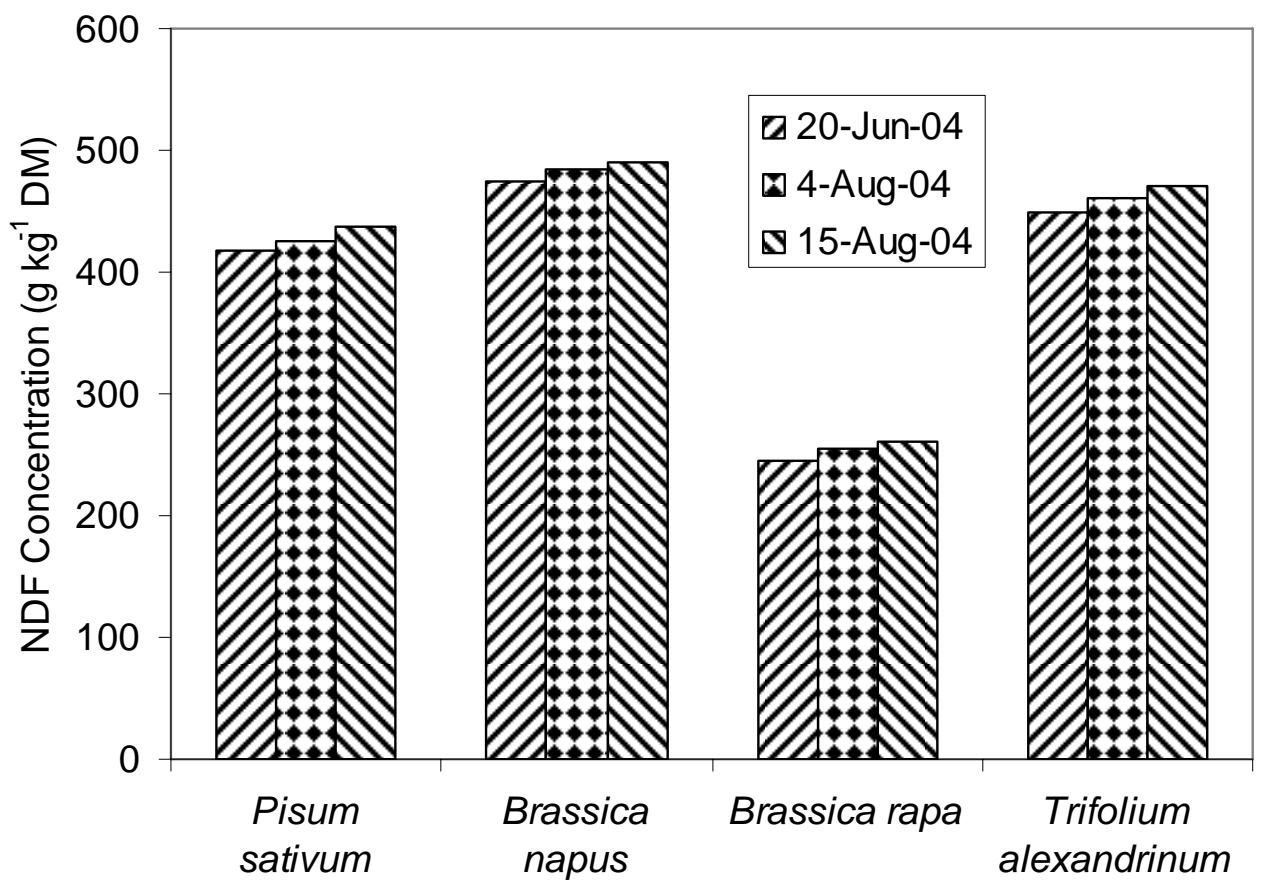

Fig. (3). Total aboveground forage neutral detergent fiber (NDF) concentrations of seeded forages sampled 20 June 2004 (17 DAP), 4 August 2004 (73 DAP) and 15 August 204 (84 DAP).

Legumes are generally superior to grasses on pastures in terms of protein and mineral concentration and their nutritive quality values decline less with age. The CP and NDF for the forages in this study were higher than $140 \mathrm{~g} \mathrm{~kg}^{-1} \mathrm{DM}$ and less than $500 \mathrm{~g} \mathrm{~kg}^{-1} \mathrm{DM}$, respectively, which provides a relative nutritive value index of $>140$ [18] and would be able to meet the nutritive requirements of deer [19].

\section{Forage Utilization and Feeding Preference}

Biomass availability was higher $(\mathrm{P}<0.05)$ in canola and turnip than berseem clover and field pea (Table 2). Absolute herbage utilization levels did not vary significantly among the four forages (Table 2). In contrast, relative herbage utilization differed $(\mathrm{P}<0.05)$ among forage types, with berseem clover higher than field pea and field pea higher than both canola and turnip (Table 2). Thus, even though berseem clover and field pea had the lowest available biomass, deer showed greater utilization specifically of these species, indicating relatively high preferences for these species. Low NDF concentrations partially explain why deer preferred these forages. A possible reason for turnips being the least preferred forage of the four is the presence of a moderate to strong astringent flavour when ingesting the turnips.

Forage type had a significant effect on where deer preferred to graze both within each trial period (early, mid, and late $)(p<0.001)$ and during the entire trial $(p<0.0001)$ (ANOVA results not shown). Across the whole trial, deer preferred to graze berseem clover, followed by field pea, turnips and canola (Table 3). Among specific trial periods the pattern of preference remained high for berseem and low in canola, with preference for field pea and turnips varying. Canola use by deer was particularly low of all the forage types and plant phenological stage. After full bloom, approximately 5-10 days prior to the start of the grazing trial, canola had started to grow pods, set seed, switching from vegetative to reproductive growth, followed by initiation of the ripening process causing a change in preference by deer. Field pea preference was equal to berseem clover until the last period of the trial, at which time preference for this 
Table 2. Comparison of Mean (SE in Parentheses) Forage Availability, Absolute and Relative Utilization White-Tailed Deer Offered 4 Seeded Annual Forages

\begin{tabular}{|c|c|c|c|}
\hline \multirow{2}{*}{ Forage Type } & Forage DM & Absolute DM & \multicolumn{1}{|c|}{ Relative } \\
\cline { 2 - 4 } & Availability (kg ha-1) & Utilization (kg ha-1) & Utilization (\%) \\
\hline \hline Pisum sativum & $3001(220) \mathrm{b}^{\mathrm{z}}$ & $1873(440) \mathrm{a}$ & $41.8(6.5) \mathrm{b}$ \\
\hline Brassica napus & $11196(663) \mathrm{a}$ & $2435(580) \mathrm{a}$ & $20.7(5.0) \mathrm{c}$ \\
\hline Brassica rapa & $9208(663) \mathrm{a}$ & $2270(540) \mathrm{a}$ & $22.5(6.0) \mathrm{c}$ \\
\hline Trifolium alexandrinum & $4368(322) \mathrm{b}$ & $2935(586) \mathrm{a}$ & $66.4(7.3) \mathrm{a}$ \\
\hline
\end{tabular}

${ }^{\mathrm{Z}}$ Within a column, means with different letters differ, $\mathrm{p}<0.05$.

Table 3. Proportion (\%) of Total Deer Grazing Seeded Annual Forages from 3-15 August, 2004

\begin{tabular}{|c|c|c|c|c|}
\hline Grazing Period & Pisum sativum & Brassica napus & Brassica rapa & Trifolium alexandrinum \\
\hline \hline Early (days 3-6) & $\mathrm{A}^{\mathrm{z}} 45.5(8.3) \mathrm{a}^{\mathrm{y}}$ & B 2.0 (0.5) c & B 10.6 (3.8) b & A 42.0 (8.0) a \\
\hline Mid (days 7-9) & A 37.2 (9.6) a & A $6.8(2.6) \mathrm{c}$ & B 17.6 (3.6) b & A 38.4 (8.6) a \\
\hline Late (days 10-12) & B 9.7 (3.6) b & A 12.3 (3.3) b & A 29.9 (6.6) a & A 48.2 (9.6) a \\
\hline Entire Period (days 1-12) & $32.3(5.0) \mathrm{b}$ & $6.5(1.5) \mathrm{d}$ & $18.5(3.5) \mathrm{c}$ & $42.8(5.4) \mathrm{a}$ \\
\hline
\end{tabular}

${ }^{\mathrm{z}}$ Within a column, means with different uppercase letters are significantly different $(\mathrm{P}<0.05)$

${ }^{\mathrm{y}}$ Within a row, means with different lowercase letters are significantly different $(\mathrm{P}<0.05)$.

forage type sharply declined coincident with reduced biomass as a result of high utilization. Field pea and berseem clover were both high yielding and high quality; a finding that supports other research in western Canada [2, 9]. In contrast, preference for turnip increased to $29.9 \%$, suggesting deer switched from field pea to turnips with time (Table 3).

\section{CONCLUSIONS}

Evaluations of forages for deer pasture require several considerations including palatability, seasonal nutritional needs and forage yield. Based on this study, these conclusions can be drawn: (1) Annual forages of field pea, canola, turnips and berseem clover can provide suitable DM yield to complement those from perennial pastures. (2) The quality of these annual forages, together with associated deer preference indicates they can be excellent pasture forage for deer. (3) Inclusion of these annual forages into deer grazing system should involve careful planning and crop management to ensure they are timed with forage demand.

\section{ACKNOWLEDGEMENTS}

Financial support was provided by the Alberta Agricultural Research Institute (Project 2003A061R) and the Natural Sciences and Engineering Research Council of Canada. Other support is acknowledged from the Departments of Renewable Resources and Agricultural, Food and Nutritional Science at the University of Alberta. We appreciate the assistance of Alberta Best Deer Group Ltd. for accommodating our study and providing in-kind support.

\section{REFERENCES}

[1] Ross SM, King JR. Berseem clover in binary mixtures with oats, triticale or barley for silage and late season grazing. Proc. XIX Int. Grassld. Congress, Sao Paulo, Brazil 2001.
[2] Fraser J, McCartney D, Najda H, Mir Z. Yield potential and forage quality of annual forage legumes in southern Alberta and northeast Saskatchewan. Can J Plant Sci 2004; 84: 143-55.

[3] Thompson DJ, Stout GG. Mixtures of Persian clover with Italian ryegrass or barley-Italian ryegrass for annual forage. Can J Plant Sci 1997; 77: 579-85.

[4] Wescott MP, Welty LE, Knox ML, Prestbye LS. Harvest management effects on yield and quality of small-seeded annual legumes in Western Montana. Montana Agric Res 1991; 8: 18-21.

[5] Kunelius HT, Narasimhalu P. Yields and quality of Italian and Westerwolds ryegrass, red clover, alfalfa, birdsfoot trefoil, and Persian clover grown in monocultures and ryegrass-legume mixtures. Can J Plant Sci 1983; 63: 437-42.

[6] Shrestha A, Hesterman OB, Squire JM, Fisk JW, Sheaffer CC. Annual medics and berseem clover as emergency forages. Agron J 1998; 90: 197-201.

[7] Panciera MT, Sparrow SD. Effects of nitrogen fertilizer on dry matter and nitrogen yields of herbaceous legumes in interior Alaska. Can J Plant Sci 1995; 75: 129-34.

[8] Ross SM, King JR, O'Donovan JT, Spaner D. Forage potential of intercropping berseem clover with barley, oat or triticale. Agron J 2004; 96: 1013-20.

[9] Ross SM, King JR, O'Donovan JT, Spaner D. The productivity of oats and berseem clover intercrops. I. Primary growth characteristics and forage quality at four densities of oats. Grass Forage Sci 2005; 60: 74-86.

[10] Association of Analytical Chemists. AOAC official method 990.03 Protein by nitrogen gas analyzer utilizing induction furnace and thermal conductivity (LECO FP-528). Official methods of analysis of AOAC international, 16th ed, International, Gaithersburg, MD 1995.

[11] Komarek AR. An improved filtering technique for the analysis of neutral detergent fiber and acid detergent fiber utilizing the filter bag technique. J Anim Sci 1993; 71: 824-9.

[12] Bork EW, Werner SJ. Viewpoint: Implications of spatial variability for estimating forage use. J Range Manage 1999; 52: 151-6.

[13] Statistical Analysis Software. SAS Institute Inc version 9.1. Cary, NC, USA. 275132002.

[14] Brink GE, Fairbrother TE. Forage quality and morphological components of diverse clovers during primary spring growth. Crop Sci 1992; 32: 1043-8.

[15] Martiniello P. Effects of irrigation and harvest management on drymatter yield and seed yield of annual clovers grown in pure stand 
and in mixtures with graminaceous species in a Mediterranean environment. Grass Forage Sci 1999; 54: 52-61.

[16] Duke JA. Trifolium alexandrinum L. In: Duke JA, Ed. Handbook of legumes of world economic importance. New York: Plenum Press 1981; pp. 234-237.

[17] Guessous F. Age, date of cutting, and temperature as factors affecting chemical composition of berseem (Trifolium alexandrinum L.). Proc. XIV Int. Grassld. Congress, Lexington: Kentucky 1981; pp. 475-8.

[18] Van Soest PJ. Nutritional ecology of the ruminant. $2^{\text {nd }}$ ed. Comstock Publishing Associates, Cornell University Press, Ithaca, NY 1994.

[19] Feist MS. Evaluation and development of specialized livestock diets in Saskatchewan. M.Sc. Thesis. University of Saskatchewan 1998.

(C) Chapman et al.; Licensee Bentham Open.

This is an open access article licensed under the terms of the Creative Commons Attribution Non-Commercial License (http: //creativecommons.org/licenses/by$\mathrm{nc} / 3.0 /$ ) which permits unrestricted, non-commercial use, distribution and reproduction in any medium, provided the work is properly cited. 